DARIUSZ DZIADOSZ, PRZEMYŚL

\title{
ŹRÓDŁA O TOLI I JAIRZE W DEUTERONOMISTYCZNEJ STRUKTURZE KSIĘGI SĘDZIÓW
}

Zwięzłe teksty źródłowe o Toli, synu Puy (10,1-2), i Jairze z Gileadu (10,3-5) tworzą pierwszy w Księdze Sędziów zbiór tradycji poświęcony sędziom mniejszym. ${ }^{1} \mathrm{~W}$ nieodległym kontekście natrafić można na jeszcze jeden, nieco obszerniejszy, cykl bliźniaczych przekazów opowiadający o Ibsanie (12,8-10), Elonie (12,11-12) i Abdonie, synu Hillela z Pireatonu (12,13-15). Obydwa te zbiory uderzają dużym pokrewieństwem formy i treści, które sugeruje nie tylko wspólne pochodzenie, ale i pierwotną spójność literacką materiału źródłowego 10,1-5 i 12,8-15. W aktualnej strukturze księgi tych pięć krótkich anegdot zostało rozdzielonych na dwa niezależne kompleksy, które deuteronomistyczny redaktor wykorzystał jako narracyjne spoiwo łączące trzy najobszerniejsze tradycje o sędziach większych: Gedeonie i Abimeleku (6,1 - 9,57), Jefte $(10,6$ - 12,7) i Samsonie (13,1 - 16,31).

Zasadniczym celem tej publikacji będzie gruntowna analiza literacka i egzegetyczno-teologiczna pierwszych dwu przekazów $(10,1-5)$ oraz próba rekonstrukcji procesu ich redakcji. Wyjątkowej atencji badawczej wymaga zarówno materiał źródłowy, jak i redakcyjna aktywność deuteronomistycznego redaktora księgi, który te tradycje odnalazł, przeredagował, poszeregował, według przyjętych wcześniej założeń literackich i teologicznych, i wpisał w sekwencję przekazów o sędziach większych.

Już na wstępie należy podkreślić dużą potrzebę krytycznego opracowania tych bardzo ciekawych tekstów źródłowych. Szczegółowej

1 Pierwszym sędzią mniejszym jest Szamgar, ale poświęcona mu tradycja jest zaledwie jednowierszową notą biograficzną $(3,31)$, całkowicie odizolowaną od pięciu pozostałych przekazów źródłowych (10,1-5; 12,8-15). 
analizy ich profilu historycznego i literackiego wciąż brakuje w obcojęzycznej i polskiej literaturze biblijnej. Poza kilkoma niewielkimi publikacjami, szkicującymi biblijny kontekst okresu sędziów mniejszych i podstawowe przesłanie poświęconych im tradycji, ${ }^{2}$ informacje w tej materii można znaleźć jedynie w komentarzach do Księgi Sędziów. Z uwagi na obszerność tych opracowań, jest to jednak wiedza o charakterze tylko ogólnym i wybiórczym.

\section{Kontekst historyczny tradycji o sędziach mniejszych}

Szczegółową analizę egzegetyczną tekstów o Toli i Jairze należy rozpocząć od kilku zasadniczych informacji, które pozwolą właściwie zrozumieć ich literacki i teologiczny profil oraz tło historyczno-kulturowe opisywanych w nich postaci i zdarzeń. Tolę, Jaira i czterech innych lokalnych przywódców przedmonarchicznego Izraela, czyli Ibsana, Elona, Abdona (12,8-15) i Szamgara (3,31), zalicza się do grona sędziów mniejszych. Z kolei Otniela, Ehuda, Baraka (Deborę), Gedeona, Jefte i Samsona, którzy w księdze są ukazywani jako charyzmatyczni wojownicy i militarni wodzowie, określa się mianem sędziów większych. ${ }^{3}$ Wszystkie te postacie Biblia utożsamia z wodzami

2 M. B a r r e d o, Aspectos sintácticos de Jueces 10,1-12,15, Anton 77/2002, s. 211-233; B. B e e m, The Minor Judges. A Literary Reading of Some Very Short Stories, w: K. Y o u n g e r (red.), The Biblical Canon in Comparative Perspective, ANETS 11, E. Mellen, Lewiston 1991, s. 147-172; A. H a u s e r, The Minor Judges A Re-evaluation, JBL 94/1975, s. 190-200; t e n ż e, Unity and Diversity in Early Israel before Samuel, JETS 22(1979)4, s. 289-303; H. H e r t z b e r g, Die kleinen Richter, TLZ 79/1954, s. 285-290; J. H u g h e s, Secrets of the Times. Myth and History in Biblical Chronology, JSOT.S 66, JSOT Press, Sheffield 1990; E. M u 11 e n, The Minor Judges: Some Literary and Historical Considerations, CBQ 44/1982, s. 185-201; R. N e 1 s o n, Ideology, Geography, and the List of Minor Judges, JSOT 31/2007, s. 347-364; A. S c h e re r, Die kleinen Richter und ihre Funktion, ZAW 119/2007, s. 190-200; Z. W e i s m a n, Charismatic Leaders in the Era of the Judges, ZAW 89/1977, s. 399-411.

3 Tytuły „sędziowie mniejsi” i „sędziowie więksi” są pozabiblijnymi kategoriami powstałymi na zasadzie analogii do podziału na proroków mniejszych i większych, a podstawowym kryterium decydującym o przynależności do jednej z tych grup 
wywodzącymi się z najsilniejszych wówczas rodów hebrajskich, którzy sprawowali w Izraelu mniej lub bardziej rozległą i suwerenną władzę przed narodzinami instytucji monarchii. Ogólnie rzecz biorąc, sędziowie więksi i mniejsi pełnili podobne funkcje w różnych regionach zdobytego przez Jozuego Kanaanu, choć czynili to w nieco innych uwarunkowaniach historyczno-społecznych. W zależności od konkretnych potrzeb hebrajskich klanów i pokoleń, oraz dynamicznie zmieniającej się w tej epoce sytuacji politycznej, władza i kompetencje sędziego obejmowały zazwyczaj sferę aktywności militarnej i administracyjno-społecznej, a niekiedy wkraczały też w dziedzinę religii i kultu. Nie ulega wątpliwości, że zakres i specyfika władzy sędziów z epoki przedmonarchicznej znacznie odbiegały od kompetencji i zadań, jakie stawia się współczesnym reprezentantom sektora administracyjno-sądowniczego. Rządy tych lokalnych przywódców były mocno ograniczone przestrzennie i znacznie ustępowały pod względem autorytetu i siły oddziaływania ukształtowanej niedługo później instytucji monarchy (1Sm 7,2 -12,25).

Symetryczny podział na sześciu większych i sześciu mniejszych sędziów, jak też ogólną liczbę dwunastu sędziów, należy interpretować w kategorii paradygmatu teologicznego wpisującego się w powszechnie przyjętą koncepcję historiografii Izraela, w której liczba „dwanaście” odgrywa zasadniczą rolę. ${ }^{4}$ Choć prawie wszyscy wspomniani

jest doniosłość misji spełnionej przez konkretnego bohatera, a także obszerność i literacko-teologiczny walor poświęconych mu tradycji pisanych. Na podstawie materiału źródłowego zgromadzonego w sekcji 10,1 - 12,15 należy wnioskować, że sędziowie mniejsi byli lokalnymi liderami sprawującymi jednocześnie władzę ustawodawczą, wykonawczą i sądowniczą w podległych sobie grupach etnicznych i nie prowadzili działań militarnych. Jedynym wyjątkiem w tej materii był Tola, a wcześniej Szamgar (10,1a; por. 3,31). Z kolei sędziowie więksi cieszą się statusem charyzmatycznych wodzów i wyzwolicieli, którzy w ekstremalnych okolicznościach wojny lub ucisku przyczyniali się do wyzwolenia spokrewnionych z nimi społeczności, którym na ten czas przewodzili z woli samego Boga lub mandatu lokalnej władzy (Otniel, Ehud, Barak, Gedeon, Jefte).

4 A. A 1 t, The Origins of Israelite Law, w: R. W i 1 s o n (red.), Essays on Old Testament History and Religion, Basil Blackwell, Oxford 1966, s. 102; t e n ż e, The Monarchy in the Kingdoms of Israel and Judah, w: tamże, s. 247. W tym kluczu 
wyżej bohaterowie są nazywani sędziami (šoptîm $\left.{ }^{5}\right)$ Izraela, to jednak każdy z nich walczył z najeźdźcą, a potem sprawował rządy w czasie pokoju w inny, sobie tylko właściwy sposób. Zgodnie $\mathrm{z}$ biblijną rekonstrukcją tego okresu historii Izraela, kolejno opisani w księdze sędziowie działali najczęściej na własnym terenie, czyli bronili wolności i dbali o dobrobyt swoich rodów, a co najwyżej zabiegali o interesy spokrewnionych lub sprzymierzonych z nimi klanów czy pokoleń.

teologicznym należy rozumieć wspomniany wyżej przekaz o Szamgarze $(3,31)$, który swą obszernością, strukturą literacką oraz perspektywą teologiczną odbiega od wszystkich pozostałych tradycji i jest powszechnie uważany za późną glosę, która miała na celu dopełnienie liczby sześciu sędziów mniejszych, a w konsekwencji dwunastu sędziów Izraela. W konsekwencji tej interpolacji - choć opisywani w księdze liderzy nie reprezentują wszystkich dwunastu pokoleń Izraela - deuteronomistyczy redaktor realizuje jeden ze swych sztandarowych celów teologicznych: pokazuje, że jego dzieło jest historią całego narodu wybranego.

5 Na określenie publicznej aktywności większości swych bohaterów redaktor księgi stosuje ten sam hebrajski rdzeń $s ̌ t t$, który legitymuje się rozległym polem semantycznym, oscylującym wokół szeroko pojętej idei sprawiedliwości społecznej: „sądzić”; ,sprawować władzę”; „zaprowadzić sprawiedliwość”; ,przywrócić zachwiany porządek społeczny". W przypadku biblijnych sędziów rdzeń ten nabiera wyraźnego zabarwienia militarnego i społeczno-administracyjnego. Występuje tak w formie czasownikowej šāpaț: „,sądzić”, ,prowadzić aktywność militarną i jurydyczną”, jak i rzeczownikowej šōpēt: ,„sędzia”, „wyzwoliciel”. Tak deuteronomista określa: Otniela (3,10), Jaira (10,3), Jefte (12,7), Ibsana (12,8), Elona (12,11) i Abdona $(12,13)$. W odniesieniu do Toli $(10,1-2)$ i Samsona $(13,5 ; 15,20 ; 16,31)$ używa zarówno określeń wyprowadzonych z rdzenia špt, jak i ǰs‘ : ,zbawiać”, ,wyzwalać”, ,uwalniać”. Wyjątkową sytuację w tym względzie notuje się w przypadku Debory, która prócz funkcji sędziny (šoptâa), anachronicznie sprawuje urząd prorokini ( $n^{e} b \hat{\imath} ' \hat{a}$; 4,4-5). Na uwagę zasługuje też charakter władzy piastowanej przez Gedeona i jego syna Abimeleka, ponieważ Biblia w tradycjach im poświęconych po raz pierwszy mówi o instytucji króla (melek) w Izraelu. Ta ostatnia kwestia jest jednak mocno dyskusyjna z uwagi na specyficzny rodzaj niektórych źródeł wchodzących w skład cyklu 6,1-9,57, które zostały wyraźnie naznaczone późną teologiczną elaboracją deuteronomistyczną krytycznie nastawioną do monarchii. Zgodnie z jej założeniami, Gedeon jest ukazany jako sędzia zdecydowanie odrzucający propozycję objęcia władzy królewskiej w Izraelu (8,22-23), zaś jego syn, Abimelek, zostaje zaprezentowany jako wykluczony z kręgu sędziów uzurpator (9,1-57), który sprowadza haniebną śmierć na siebie i swych popleczników. 
Tylko niektórzy z nich stawali na czele zbrojnych oddziałów Izraela złożonych z kilku pokoleń i walczyli z regularną armią wroga (Otniel, Ehud, Barak, Gedeon, Jefte), zyskując miano biblijnych wyzwolicieli (môšîa $)$. Inni na polu walki działali w pojedynkę (Szamgar, Samson), jeszcze inni (Jair, Ibsan, Elon, Abdon) wcale nie musieli chwytać za broń, gdyż działali w okresie względnego pokoju i mogli skoncentrować wysiłki na polu administracyjno-społecznym i rozjemczo-sądowym w obrębie własnych klanów i rodów.

Na podstawie dostępnych źródeł biblijnych można założyć, że rządy kolejno opisanych sędziów ograniczały się do stosunkowo wąskiego terytorium i ściśle określonych ram czasowych. W przypadku niektórych sędziów inicjowały je sukcesy militarne odniesione na polu walki z najeźdźcą, w pozostałych były podyktowane prawdopodobnie zajmowaną przez nich pozycją społeczną lub pełnioną funkcją. Żadnemu z sędziów nie udało się zmienić statusu piastowanej władzy ani przedłużyć jej na następne pokolenie. Jedyną, ale tylko po części, udaną próbę w tym względzie zanotowano w czasach Gedeona i jego synów $(8,22-23 ; 9,1-57)$. Na podstawie treści zachowanych w księdze przekazów można przypuszczać, że zakusy wprowadzenia władzy dziedzicznej na podległym sobie terytorium mogli przejawiać sędziowie: Jair (10,3-5), Ibsan (12,8-10) i Abdon (12,13-15), opierając swe polityczne aspiracje na silnym prestiżu społecznym i dużej zamożności swych rodów. To, że Księga Sędziów prezentuje swych bohaterów jako wodzów całego Izraela, a niektórym przypisuje nawet bardzo długi - zwykle okrągły i symboliczny (por. 3,30; 5,31b; 8,28; 15,20; $16,31 b)$ - okres sprawowania rządów, nie odzwierciedla ówczesnych realiów historycznych, lecz jest konsekwencją teologicznej optyki redaktora. Deuteronomistyczna historiografia Izraela (Joz-2Krl) znana jest bowiem z tego, że nawet lokalne wydarzenia i postacie ukazuje w perspektywie teologicznego uniwersalizmu jako dzieje całego narodu wybranego dokonujące się przy bezpośrednim zaangażowaniu Boga JHWH. Ta teologiczna optyka towarzyszy deuteronomistycznej relacji wydarzeń od podboju Kanaanu w epoce Jozuego aż po utratę Ziemi Obiecanej w wyniku najazdu asyryjskiego (2Krl 17) i babilońskiego (2Krl 23-25). 
Łatwo zauważyć, że z największym rozmachem księga mówi o sędziach większych, podkreślając równocześnie dobre i mało chwalebne strony ich postawy i aktywności. Deuteronomista skupia się na sile ducha JHWH oddziałującego przez tych charyzmatycznych wodzów, a także ich osobistych walorach i predyspozycjach pomagających odnieść zwycięstwo nad wrogiem, ale równie mocno akcentuje ich niewierność i słabość, które przesądzają o tylko częściowym sukcesie misji realizowanej z mandatu Boga. Jeśli chodzi o charyzmaty sędziów większych i mniejszych, to redaktor księgi zwraca najczęściej uwagę na ich militarne umiejętności i doświadczenie, nieustraszoną odwagę, strategiczną rozwagę, a nierzadko spryt i przebiegłość. $\mathrm{Z}$ dużo mniejszą atencją podchodzi natomiast do ich aktywności administracyjno-prawnej czy społeczno-politycznej bezpośrednio po zakończeniu walki wyzwoleńczej i w okresie pokoju.

Lakoniczne i bardzo ubogie informacje zawarte w 3,31; 10,1-5; 12,8-15 nie pozwalają precyzyjnie określić kompetencji i sposobu sprawowania władzy przez sędziów mniejszych. Deuteronomistyczny redaktor księgi świadomie umieścił ich życie i misję w cieniu zdarzeń związanych z szeroko opisaną aktywnością militarną i administracyjną charyzmatycznych wyzwolicieli. Spośród sześciu sędziów mniejszych tylko Szamgar może nosić imię rzeczywistego wyzwoliciela, który wsławił się wielkim męstwem i pokonaniem aż sześciuset Filistynów za pomocą prymitywnego narzędzia rolniczego $(3,31)$, czym dorównał wyczynom Otniela, Ehuda, Baraka, Gedeona, Jefte czy Samsona. Aktywność zbawczą przypisuje się też Toli $(10,1)$, ale nie mówi się nic ani o jego wrogach, ani przykładach jego męstwa manifestowanych na polu walki. Miejsce Toli, Jaira, Ibsana, Elona i Abdona w gronie biblijnych sędziów uzasadnia fakt, że wszyscy sprawowali sądy w Izraelu $(10,2.3 ; 12,8.11 .13)$, to znaczy mieli realną władzę, choć ograniczała się ona jedynie do lokalnych terytoriów i rozumiana była w sensie administracyjno-jurydycznym. To, że zwani są sędziami mniejszymi nie oznacza, że zasługi społeczno-polityczne, jakie położyli dla poszczególnych regionów Izraela, były znacząco mniejsze od tych, którymi legitymowali się ich więksi odpowiednicy. Status i pozycja sędziów mniejszych jest w księdze 
uwarunkowana w dużej mierze charakterem tradycji opisujących ich życie i działalność publiczną, które cechuje widoczne gołym okiem ubóstwo źródłowe, schematyzm i prostota literackiego wyrazu. Należy przypuszczać, że i te względy przyczyniły się do tego, iż te postacie miały dla deuteronomistycznego redaktora księgi charakter raczej drugoplanowy. ${ }^{6}$

Jak wynika z biblijnych źródeł, społeczno-polityczny status i rzeczywiste kompetencje sędziego były dość szerokie i zawsze uwarunkowane specyfiką sytuacji historycznej, w której żył i działał. Z niektórych tekstów wyłania się figura głowy rodu, która swym społecznym i moralnym autorytetem czuwa nad praworządnością życia i troszczy się o dobrobyt rodzimego klanu lub pokolenia. W innych spotyka się postać lokalnego możnowładcy i społeczno-politycznego lidera ( $s \bar{a} r$ w 5,15; 7,25; 8,6; rō’š i qāṣ̂in w 11,8-11), który rozciąga swe wpływy na sąsiadujące miejscowości, miasta lub regiony na podobieństwo kananejskich możnowładców czy królów dzierżących władzę nad konfederacjami blisko położonych oraz gospodarczo i politycznie związanych ośrodków. Pozostałe tradycje promują ideę nieugiętego wojownika, który swą nieustraszoną odwagą i męstwem zapalał rodaków do walki o niepodległość i poprawę warunków bytowych, a następnie w okresie zaprowadzonego przez siebie pokoju sprawował rządy w ramach obowiązującego w Izraelu modelu teokracji. Księga zawiera też bogaty przekaz poświęcony figurze miejscowego zawadiaki i awanturnika, który - świadomy swej nadludzkiej siły - rzuca wyzwanie lokalnemu okupantowi, ale nie czyni tego z pobudek religijnych czy patriotycznych (13,1-16,31). Samson, bo o nim tutaj mowa, nigdy nie staje na czele wojsk izraelskich. Prowokuje groźnych Filistynów i wchodzi z nimi w słowne, a potem krwawe utarczki z motywów osobistych, nie dbając o porządek moralny i sprawiedliwość w obrębie swego rodu czy otrzymany od JHWH charyzmat nazirejczyka i sędziego.

6 H. Rö s e 1, Die „Richter Israels“. Rückblick und neuer Ansatz, Biblische Zeitschrift 25/1981, s. 180-203. 


\section{Charakterystyka literacka, proces redakcji i aktualne miejsce przekazów o Toli i Jairze}

Materiał źródłowy poświęcony sędziom mniejszym można znaleźć wyłącznie w Księdze Sędziów. Jego aktualne miejsce w strukturze księgi i specyfika literacka dowodzą, że poddany został procesowi wieloetapowej transformacji i stał się przedmiotem wielu zaplanowanych interwencji redakcyjnych. Pierwsza biblijna prezentacja przedstawiciela tej grupy sędziów ma kształt niezmiernie krótkiej, bo zaledwie jednowierszowej, noty biograficznej i jest zadedykowana Szamgarowi, synowi Anata (3,31). Notę tę deuteronomista zamieścił bezpośrednio po materiale opisującym aktywność militarną dwóch pierwszych sędziów większych: Otniela (3,7-11) i Ehuda (3,12-30). Pozostałymi reprezentantami tej sześcioosobowej grupy bohaterów są kolejno: Tola (10,1-2), Jair (10,3-5), Ibsan (12,8-10), Elon (12,11-12) i Abdon (12,13-15). Za aktualnym kształtem relacji o sędziach mniejszych stoi redaktor deuteronomistyczny, który wpierw zebrał dotyczący ich materiał źródłowy mający prawdopodobnie formę listy lokalnych bohaterów Izraela wzbogaconej zwięzłym i schematycznym materiałem narracyjnym opisującym ich rządy. ${ }^{7}$ Następnie opracował jego kształt literacki i teologiczny, a potem wyznaczył mu miejsce w korpusie księgi, kierując się kryteriami, które dziś trudno jednoznacznie sprecyzować. W ten sposób krótkie sprawozdania z rządów Toli $(10,1-2)$ i Jaira $(10,3-5)$ znalazły się po podwójnym cyklu bardzo obszernych przekazów opowiadających o dziejach Debory i Baraka $(4,1-5,31)$ oraz Gedeona i jego niegodziwego syna Abimeleka (6,1-57). Patrząc na treść i formę tych tradycji, można dopatrywać się pewnych zależności i próbować zrozumieć literacką i teologiczną strategię deuteronomisty. Trudno jest jednak znaleźć definitywną odpowiedź na pytanie o rzeczywiste cele redakcyjne,

7 Do takich wniosków można dojść na bazie analizy porównawczej aktualnej biblijnej wersji przekazów o sędziach mniejszych $(10,1-5 ; 12,8-15)$ z nieporównywalnie bardziej złożonymi pod względem literackim i teologicznym tradycjami i cyklami tradycji o sędziach większych $(3,8-30 ; 4,1-9,57 ; 12,8-16,31)$. 
jakie przyświecały redaktorowi księgi podczas opracowywania materiału źródłowego o sędziach mniejszych. Wszystkie przytoczone niżej sugestie będą mieć zatem charakter jedynie mniej lub bardziej wiarygodnej hipotezy badawczej.

Szukając motywów, jakimi kierował się deuteronomista w dysponowaniu materiałem tekstualnym poświęconym sędziom mniejszym w obrębie księgi, na początku trzeba zauważyć, że teksty o Deborze i Baraku oraz Gedeonie i Abimeleku są jedynymi w obrębie dzieła, które nie dotyczą pojedynczych postaci, lecz par równoprawnych bohaterów. Być może ten czynnik zadecydował o tym, że w celu osiągnięcia strukturalnej symetrii sekcji redaktor księgi wybrał z oryginalnej pięcioelementowej listy lokalnych przywódców Izraela $(10,1-5 ; 12,8-15)$ dwie krótkie anegdoty relacjonujące rządy Toli i Jaira i zamieścił je bezpośrednio po sekcji 4,1 - 9,57. Następnie za pomocą materiału źródłowego o sędziach mniejszych redaktor chciał połączyć w jedną spójną literacką całość także obszerne relacje o Gedeonie i Abimeleku $(6,1-9,57)$, Jefte $(10,6-12,7)$ i Samsonie $(13,1-16,31){ }^{8}$ Pretekstem do takiego rozwiązania mogła być też treść zamknięcia cyklu tradycji o Jefte $(12,7)$, która powiela w pewnej mierze schemat strukturalny przekazów o sędziach mniejszych $(10,1-5 ; 12,8-15) .{ }^{9} \mathrm{Re}-$ daktor mógł się zasugerować tą tematyczną i strukturalną zbieżnością do tego stopnia, że właśnie wokół cyklu o Gileadczyku (10,6 - 12,7) ulokował przekazy o Toli, Jairze, Ibsanie, Elonie i Abdonie. Trudno jest bowiem szukać genezy cyklu o Jefte w odwrotnym kierunku, czyli podzielać pogląd tych egzegetów, którzy zaliczają tego wyzwoliciela do katalogu sędziów mniejszych, a wiersz 12,7 traktują jako fundament, na którym zbudowano obszerne opowiadanie o wyzwolicielu z Gileadu $(10,6-12,7)$.

Powód, dla którego przekaz o Jefte został opasany podwójną serią tekstów o sędziach mniejszych, może mieć też wymiar teologiczny.

8 S. Fr o lo v, Judges, FOTL, Eerdmans Publishing, Grand Rapids 2013, s. 18.

9 Do takiego wniosku prowadzi podobna sekwencja informacji mówiących o długości sprawowanej władzy, śmierci i pogrzebie bohatera w epilogu cyklu o Jefte $(12,7)$ oraz w podsumowaniach tradycji o sędziach mniejszych. 
Otóż w całej księdze tylko Jefte i opisany wcześniej Abimelek nie podejmują misji z woli JHWH, lecz z mandatu swoich środowisk. Okoliczności dojścia do władzy Abimeleka i Jefte są bardzo podobne i opierają się na ugodzie społeczno-politycznej z lokalną władzą. Ponadto w tekstach o Gedeonie i Abimeleku po raz pierwszy dochodzi do głosu motyw monarchii (władzy dziedzicznej) (8,22-23; 9,1-21), na który w pewien sposób wskazują także niektóre teksty o sędziach mniejszych $(10,4 ; / 12,9 / ; 12,14) .{ }^{10}$

Motywem, dla którego historia o Jefte $(10,6$ - 12,7) zyskała specyficzne ramy literackie w postaci bardzo podobnych do siebie tradycji o sędziach mniejszych, może być też jej centralna pozycja, jaką zajmuje w strukturze księgi. Ponadto krótki materiał 12,8-15 między tradycjami o Jefte i Samsonie pozwala stworzyć odpowiedni narracyjny pomost łączący te dwa obszerne i tak odmienne od siebie kompleksy, a zarazem zaakcentować niezwykły literacki walor najbardziej reprezentatywnej i bogatej pod względem narracyjnym opowieści o charyzmatycznym nazirejczyku z Sorea $(13,1-16,31)$.

Umieszczenie sekcji 10,1-5 i 12,8-15 wokół cyklu o Jefte może być też rezultatem społeczno-religijnego zamysłu deuteronomisty, który przez zestawienie mającego tylko jedną córkę Jefte $\mathrm{z}$ bogatymi w potomstwo: Jairem, Ibsanem i Abdonem chciał potępić jego kontrowersyjny ślub (11,30-31.34-40) i ukazać jego zgubne skutki. Wobec sędziów legitymujących się kilkudziesięcioosobowym potomstwem $(10,4 ; 12,9.14)$, które dawało perspektywę silnej dziedzicznej władzy i duży autorytet polityczny, a także zapewniało społeczną stabilizację dla rządzonego ludu, Jefte, skazujący na śmierć swą jedyną córkę, jawi się jako wódz pozbawiony zmysłu politycznego i jakichkolwiek szans na długie panowanie (por. 11,1-3). A właśnie kwestia stabilnej i dynastycznej władzy jest jednym z kluczowych wątków teologicznych, jakie rozwija deuteronomistyczny redaktor w epilogu księgi (por. 17,6; 18,1; 19,1; 21,25).

I w końcu sugestia natury topograficznej. Bliskość przekazów o Jairze $(10,3-5)$ i Jefte $(10,6$ - 12,7) tłumaczyłoby identyczne

10 B. B e e m, The Minor Judges, s. 165. 
pochodzenie obydwu bohaterów oraz ta sama lokalizacja geograficzna ich aktywności i rządów. Obaj wywodzili się z Gileadu i obaj działali na terenie swej małej ojczyzny.

Jak zaznaczono wyżej, powyższe wnioski mają wartość hipotetyczną. Trudno jest bowiem znaleźć jeden konkretny i jednoznaczny wzgląd formalny (np. podobny rodzaj literacki, schemat narracyjny, terminologia) czy merytoryczny (wspólny kontekst historyczno-kulturowy, bohaterowie, chronologia, teologia), który przekonująco tłumaczyłby miejsce tradycji o sędziach mniejszych w tej części księgi. Patrząc na pozycję tekstu o Szamgarze $(3,31)$ i umiejscowienie przekazów o Toli i Jairze (10,1-2.3-5) oraz Ibsanie (12,8-10) i Abdonie (12,13-15), stwierdza się, że nie są bezpośrednio i logicznie związane z najbliższym kontekstem narracyjnym. Notę o Szamgarze połączono z poprzedzającą ją historią Ehuda tylko za pomocą hebrajskiej formuły czasowej $w^{e}$ 'ahărājjw hājâ - ,a po nim był”, która sama w sobie nie ma specyficznego waloru znaczeniowego. W tym konkretnym kontekście mogłaby być, co prawda, wskazówką chronologiczną, ale tej ewentualności sprzeciwia się treść wiersza 4,1, który z epoką Ehuda wiąże bezpośrednio ucisk kananejski za czasów Debory i Baraka, a nie walki Szamgara z Filistynami. A zatem formuła ta jest pozostałością struktury pierwotnego zbioru przekazów o sędziach mniejszych, do którego być może należał tekst o Szamgarze (por. analogiczne formuły sugerujące następstwo chronologiczne w 10,1a.3a i 12,8a.11a.13a), albo jest owocem pracy deuteronomisty usiłującego zespolić wszystkie dostępne mu źródła w jedną literacką całość.

Identyczną sytuację można zaobserwować w krótkiej relacji o Toli, którego aktywność społeczno-polityczną redaktor księgi wiąże bezpośrednio z Abimelekiem (10,1), choć nie potwierdza swej opinii żadną konkretną informacją źródłową. W formułę sugerującą sekwencję chronologiczną wpisuje aż dwa imiona sędziów: wiersz 10,1a rozpoczyna się od zwrotu wajjākām 'ahărê 'ăbîmelek - „i powstał po Abimeleku", a zaraz po nim następuje krótka prezentacja Toli. Bliskie zestawienie i powiązanie dwu postaci w kolejnych tradycjach, w tym przypadku króla - uzurpatora oraz sędziego - wyzwoliciela, pojawia się tylko raz jeden w całym kompleksie relacji o sędziach $(3,7-16,31)$. 
Przy użyciu bardzo podobnej formuły łączącej wajjākām 'aḥ̆rājjw (,,i powstał po nim”) sugerującej następstwo czasowe zostaje wprowadzony na scenę wydarzeń także drugi interesujący nas sędzia - Jair (10,3a). Z kolei teksty o pozostałych sędziach mniejszych: Ibsanie, Elonie i Abdonie - umieszczone po burzliwej historii życia Gileadczyka Jefte $(10,6$ - 12,7) - rozpoczynają się od innej formuły: wajjišpōt 'ahărê 'et-jiśrā'èlq - ,a po nim sprawował rządy nad Izraelem" (12,8.11.13). Można więc wnioskować, że składnia otwierająca te tradycje była czymś w rodzaju strukturalnego zawiasu, który skonstruowali autorzy oryginalnych źródeł o lokalnych wodzach: Toli i Jairze, a także: Ibsanie, Elonie i Abdonie. Te schematy narracyjne przetrwały wpierw pierwsze procesy redakcyjne, kiedy pojedyncze przekazy o sędziach łączono w większe kompleksy literackie (np. listy bohaterów z epoki przedmonarchicznej). Deuteronomista zachował ten strukturalny układ również na etapie edycji księgi i wykorzystał go jako narzędzie do harmonijnego włączenia tych pięciu tekstów w sekwencję relacji o sędziach większych.

Mimo niewielkiej obszerności i wadze teologicznej tekstów o sędziach mniejszych, proces ich redakcji jest zatem dość złożony. Trudno jest dziś precyzyjnie określić ich pierwotnych autorów, można tylko przypuszczać, że byli związani ze środowiskami, z których wywodzili się opisywani liderzy. Na bazie treści i aktualnej pozycji tych tradycji wiadomo jednak, że za ich ostateczną formę literacką i funkcję, jaką pełnią obecnie w biblijnej historii przedmonarchicznego Izraela odpowiada deuteronomista. Tak więc teksty o Toli, Jairze i pozostałych sędziach mniejszych mają przynajmniej jeden wspólny etap literackiej formacji. Na bazie wskazanych wyżej trzech różnych konstrukcji składniowych: we'ahărājw hājâ (,,a po nim był”-3,31), wajjākām 'ahărê /'ahărājw/ (,,i powstał po /po nim/" - 10,1.3) oraz wajjišpōt 'aḥărê 'et-jiśrāēl (,,a po nim sprawował rządy nad Izraelem") można założyć istnienie dwu (10,1-5 i 12,8-15) albo trzech (3,31; $10,1-5 ; 12,8-15)$ oryginalnie niezależnych zbiorów tradycji. Początkowo miały one prawdopodobnie postać spisów imion lokalnych izraelskich wodzów lub wyzwolicieli, które z czasem były dodatkowo opatrywane krótszymi bądź dłuższymi notami sławiącymi ich odwagę 
i męstwo czy też zamożność i społeczny autorytet, jakim cieszyli się w zarządzanych przez siebie społecznościach. Tego typu dokumenty (listy, krótkie narracje, anegdoty) funkcjonowały zapewne już niedługo po ich śmierci w obrębie hebrajskich klanów i pokoleń, z których się wywodzili. Dopiero w rezultacie długiego procesu kształtowania się i utrwalania tradycji ustnej i pisanej stały się spójnym kompleksem(ami) krótkich relacji o sędziach - wyzwolicielach i administratorach Izraela. Ostatnim etapem redakcji tekstów 10,1-5; 12,8-15 był proces edycji Księgi Sędziów, kiedy to deuteronomista przejął je i zręcznie wpisał w antologię przekazów o charyzmatycznych wyzwolicielach Izraela, przystosowując najpierw ich literacki i teologiczny kształt do wymogów swojego dzieła. Podobieństwo, a zarazem oryginalność formuł, które wprowadzają kolejnych sędziów w 3,31, 10,1.3 i 12,8.11.13 można bowiem tłumaczyć wielością źródeł, ale także wielofazowym procesem redakcji księgi.

$\mathrm{Z}$ uwagi na zachowaną przez edytora księgi archaiczną formę krótkich not biograficznych (wykaz bohaterów wzbogacony o wychwalający ich materiał narracyjny), teksty o sędziach mniejszych stanowią konkretny i cenny punkt odniesienia w rekonstrukcji skomplikowanego procesu redakcji księgi. Trudno jest dziś orzec, czy prócz wymienionych w 10,1-5 i 12,8-15 pięciu sędziów oryginalny spis obejmował innych podobnych bohaterów. Prawdopodobnie do tego grona należał Szamgar $(3,31)$, być może figurował w nim także Jefte, na co mogłaby wskazywać struktura wiersza 12,7 przypominająca schemat summariów w sekcji 12,8-15. Niektórzy egzegeci do tej listy dodają też Otniela, którego biblijna historia (3,7-11) również powiela niektóre elementy struktury i terminologii przekazów o sędziach mniejszych. Są w końcu i tacy, którzy w tym gronie widzą Deborę $(4,4-9)$, a nawet uzurpatora Abimeleka - i tym tłumaczą treść otwarcia relacji o Toli $(10,1) .{ }^{11}$ Wszystkie te sugestie mają jednak wartość

11 W. H e r t z b e r g, Giosuè, Giudici, Rut, AT 9, Paideia, Brescia 1985, s. 325-326. Na bazie literackiej specyfiki przekazów o sędziach mniejszych niektórzy egzegeci zaliczają do tej grupy bohaterów biblijnych Samsona i Samuela. A. S c h e r e r, Simson und Schamgar. Zur Frage nach der ursprünglich Position 
hipotetyczną, którą trudno zweryfikować oraz poprzeć konkretnymi dowodami natury literackiej czy teologicznej.

Biblijne przekazy o sędziach mniejszych - poza lakoniczną notą o Szamgarze (3,31) - łączy podobny schemat strukturalny, który diametralnie różni się od teologicznego i literackiego modelu przekazów o sędziach większych. W żadnym z nich nie występuje najmniejsza aluzja do teologicznego wzorca narracyjnego deuteronomisty (2,11-23), w który zostały wpisane wszystkie przekazy o sędziach większych. ${ }^{12}$ Oryginalne anegdoty o pięciu liderach lokalnych społeczności Izraela charakteryzują się własnym tonem narracji, spójną i schematyczną strukturą, która sugeruje wspólne literackie źródło przynajmniej dla czterech z nich $(10,3-5 ; 12,8-15 ; 10,1-2$ ma nieco inną specyfikę literacką). W tekstach tych można łatwo zauważyć następujące wspólne wątki tematyczne: informacja o rządach w Izraelu $(10,2.3 ; 12,8.11 .13)$; nota o wybawieniu Izraela $(10,1 ;$ por. 3,31$)$; krótka genealogia prezentująca imię sędziego, imię jego ojca, niekiedy dalszego przodka, oraz miejsce pochodzenia, ród (10,1.3.8.11.13; por. 3,31); zwięzła nota o wyjątkowym męstwie lub pozycji społecznej bohatera (10,4.9ab.14; por. 3,31); aluzja do dziedzicznego (być może już monarchicznego) modelu sprawowania władzy (10,4; 12,9.14); informacja o długości i/lub miejscu rządów (10,2.9c.11b.14b); nota o śmierci i miejscu pochówku (10,2.5.10.12.15).

Struktura ta różni się diametralnie od schematu obszernych i pełnych archaicznego religijnego folkloru relacji o Ehudzie, Baraku, Gedeonie czy Jefte i Samsonie. Te najbardziej reprezentatywne dla księgi opowiadania zbudowane są na bazie stałego schematu narracyjnego o wyraźnej podbudowie teologicznej. Jego pełna struktura obejmuje następujące wątki tematyczne: apostazja Izraela; ucisk

der Schamgarnotiz im Richterbuch, ZAW 114/2002, s. 106-109; t e n ż e, Die kleinen Richter und ihre Funktion, s. 190-191; H. R ö s e 1, Jeptah und das Problem der Richter, Bib 61/1980, s. 251-255. Te opinie nie znajdują jednak potwierdzenia w treści materiału źródłowego utrwalonego w księdze ani w ogólnej teologicznej strukturze deuteronomistycznej historiografii Izraela (Joz - 2Krl).

12 W. Hert z be r g, Die kleinen Richter, s. 285-290; R. D e V a u x, The Early History of Israel to the Period of the Judges, Longman, London 1978, s. 752-759. 
interpretowany w kategorii Bożej odpłaty; społeczno-militarna aktywność wyzwoliciela rozumiana jako akt Bożej łaski w odpowiedzi na narzekania Izraelitów; czas pokojowych rządów wyzwoliciela (por. 3,7-11.12-30; 4,1-24; 6,1-8,28; 10,6-12,7; 13,1-16,31). Deuteronomista korzysta z tego schematu w zależności od obszerności i literackiej specyfiki oryginalnych źródeł o sędziach większych, jednak zupełnie pomija go w redakcji materiału źródłowego o sędziach mniejszych.

$\mathrm{Z}$ tego względu pięć bliźniaczych relacji o wyzwoleńczej i administracyjnej aktywności liderów Izraela w 10,1-5 i 12,8-15 wciąż ma formę krótkich summariów zbudowanych na oryginalnym schemacie strukturalnym, którego zasadnicze i powtarzające się regularnie elementy zostały określone wyżej. W schemacie tym na próżno szukać wątków teologicznych. Jedynym wyjątkiem w tej materii jest tekst o Toli, który w wierszu otwarcia odwołuje się do wyzwoleńczego (zbawczego; hebr. jāša ) charakteru jego misji (por. 3,31), choć ani słowem nie wspomina o apostazji Izraela, ucisku ze strony najeźdźcy, Bożym powołaniu czy jakichkolwiek szczegółach dotyczących wyzwoleńczej aktywności sędziego. Analizując te pięć tradycji, dochodzi się do przekonania, że pokazują inną - alternatywną dla tradycji o sędziach większych - perspektywę historyczną i teologiczną epoki przedmonarchicznej. Z uwagi na brak materiału źródłowego lub własną koncepcję redakcji dzieła ${ }^{13}$ deuteronomista rezygnuje ze szczegółowego opisu czynów tych liderów i ukazywania ich w teologicznym pryzmacie zasady Bożej retrybucji (por.

13 Niestety, do naszych czasów nie zachowało się żadne pozabiblijne źródło, które mówiłoby o sędziach mniejszych i kontekście historycznym, w którym byli aktywni. O formie, obszerności i treści tych oryginalnych źródeł można wnioskować tylko na podstawie materiału tekstualnego stworzonego przez deuteronomistycznego redaktora Księgi Sędziów. Opierając się na kształcie aktualnej wersji biblijnych tradycji o Toli, Jairze, Ibsanie, Elonie i Abdonie, można przypuszczać, że deuteronomista miał do dyspozycji rzeczywiste i konkretne źródła, na podstawie których opracował dwuelementową sekcję o tych lokalnych przywódcach społeczno-politycznych. Trudno jednak dzisiaj precyzyjnie zrekonstruować metodę, w myśl której wybierał, porządkował, redagował i wykorzystywał te źródła, przystosowując je do wymogów literackich i teologicznych swego dzieła. 
sędziowie więksi). Wprowadzając tych lokalnych przywódców do grona bohaterów przedmonarchicznego Izraela, zdaje się kierować ideą teologicznego uniwersalizmu, czyli postanawia zaprezentować tę epokę jako okres panowania 12 wodzów rozciągających swe rządy na wszystkie hebrajskie pokolenia. Na podstawie tonu krótkich sekcji 10,1-5 i 12,8-15 oraz ich motywów wiodących, lektor księgi może wnioskować, że sędziowie mniejsi byli zamożnymi i szanowanymi obywatelami, ${ }^{14}$ a zarazem doświadczonymi przywódcami sprawującymi władzę przez długi czas. Prócz dwu pierwszych, czyli Szamgara i Toli, żaden z nich nie walczył w obronie uciśnionego ludu, dlatego geneza ich rządów nie ma podtekstu militarnego, lecz administracyjny. Termin $s \bar{r} r$ („wódz”, „lokalny przywódca»”), który definiuje status ich urzędu społeczno-politycznego oraz rdzeń $\check{s} p t$ („sądzić”) nie pozwalają łączyć ich władzy z instytucją monarchii, choć mógłby na to pośrednio wskazywać literacki kontekst materiału poświęconego niektórym z nich $(10,4 ; 12,9.14)$. Niewykluczone, że ten sposób prezentacji sędziów mniejszych jest rezultatem teologicznej elaboracji deuteronomisty, który w tej partii księgi nie kryje swej antymonarchicznej postawy $(8,22-23 ; 9,1-57)$.

\section{Najważniejsze kwestie egzegetyczne tradycji o Toli (10,1-2)}

Po rekonstrukcji kontekstu historycznego, w którym sędziowie mniejsi prowadzili swą aktywność, a także prezentacji profilu literackiego i redakcyjnego tradycji im poświęconych, można przystąpić

14 Argumentem przemawiającym za taką a nie inną lekturą tych tekstów jest choćby krótka genealogia rozpoczynająca przekaz o Toli i Abdonie (10,1; por. 12,13), informacje o znacznej długości rządów Toli i Jaira $(10,2.3)$, a także noty o dużej zamożności i prestiżu społecznym Jaira, Ibsana i Abdona $(10,4 ; 12,9.14)$. Ten ton interpretacji zdaje się sugerować również charakterystyczna dla wszystkich tekstów o sędziach mniejszych w 10,1-5 i 12,8-15 informacja o ich pochówku na rodzimej ziemi $(10,2.5 ; 12,10.12 .15)$. Warto zaznaczyć, że tego rodzaju wiadomość pojawia się tylko w najważniejszych tradycjach o sędziach większych: Gedeonie i Samsonie $(8,32 ; 16,31)$ oraz przekazach o królach Izraela i Judy (por. 2Sm 21,14; $1 \mathrm{Krl} 2,10$; 11,$43 ; 14,20.31 ; 15,8.24 ; 16,6$ itd.). 
do zwięzłej analizy egzegetyczno-teologicznej materiału źródłowego 10,1-2. Krótki tekst o Toli wpisuje się w zasadzie w strukturalny schemat obecny także w pozostałych elementach sekcji 10,1-5 i 12,8-15, ale zawiera też bezpośrednie nawiązanie do oryginalnego źródła, które $\mathrm{w}$ formie ustnej lub pisanej trafiło do deuteronomistycznego redaktora księgi. Na bazie tego źródła powstała samodzielna biblijna tradycja, która rozpoczyna się od informacji o inauguracji rządów syna Puy. Formuła inicjująca tę tradycję jest poszerzona dodatkowo o krótką genealogię $(10,1 \mathrm{a} \beta)$, po czym określa się miejsce rządów sędziego $(10,1 b)$, ich długość (10,2a), a na końcu podaje się fakt jego śmierci i pogrzebu w rodzinnym mieście $(10,2 b)$. W odróżnieniu od innych tradycji o sędziach mniejszych, tekst o Toli zawiera notę chronologiczną, która pełni rolę pomostu narracyjnego $(10,1 \mathrm{a} \alpha)$, ponieważ ściśle łączy jego rządy z epoką poprzednika, Abimeleka (9,1-57). Gatunek literacki przekazu o Toli, podobnie zresztą jak wszystkich pozostałych relacji o sędziach mniejszych, można zdefiniować opisowo jako summarium o militarnej, ${ }^{15}$ a nade wszystko społeczno-politycznej aktywności lokalnego przywódcy Izraela.

Komentarz egzegetyczny 10,1-2 należy rozpocząć od prezentacji głównego bohatera, która w tym summarium jest najbardziej obszerna ze wszystkich utrwalonych w 3,31; 10,1-5; 12,8-15. Źródłosłów hebrajskiego tôla ${ }^{\prime}$ jest niejasny. Niektórzy egzegeci wiążą go z pojęciem „robak”, ${ }^{16}$ ale tekst biblijny nie zawiera żadnej etiologii, która mogłaby wskazywać na taką etymologię tego imienia. W zamian za to uzupełnia prezentację sędziego o dwa kolejne imiona: jego ojca - Puy i dziadka - Dodo (dôdô lub dōdô). Godnym szczególnej uwagi jest to, że deuteronomistyczny redaktor księgi łączy tradycję o Toli z przekazem o okrutnym i podstępnym synu Gedeona - Abimeleku, a czyni

15 Istotną cechą, która wyróżnia ten przekaz w sekcji 10,1-5; 12,8-15 jest fakt, że Tola jest postrzegany zarówno jako lokalny przywódca sprawujący władzę administracyjną i sądowniczą, jak też wyzwoliciel Izraela, który podejmował akcje zbrojne (10,1a).

${ }_{16} \mathrm{R}$. B o 1 i n g, Judges. A New Translation with Introduction and Commentary, AB 6A, Doubleday, Garden City 1975, s. 186. 
to za pomocą formuły, która w biblijnych tekstach narracyjnych oznacza chronologiczne następstwo i znajduje zastosowanie w innych tradycjach o sędziach mniejszych (por. 10,3). Aby odpowiednio zaznaczyć czasową bliskość epoki Abimeleka i Toli, deuteronomista nieco modyfikuje i rozszerza otwarcie źródłowej tradycji o synu Puy i w miejsce oryginalnej formuły otwierającej: wajjākām 'ah̆ărājw „i powstał po nim” (por. analogiczny tekst o Jairze w 10,3a), w wierszu 10,la $\alpha$ umieszcza jej bogatszy wariant: wajjākām 'ahărê 'ăbîmelek lehôšîa "et-jiśrāél tôla ${ }^{\prime}$ - „i powstał po Abimeleku dla wybawienia Izraela Tola". Korekta dokonana przez deuteronomistę nabiera w tym kontekście wielorakiego znaczenia. Przez formułę lehôšîa 'et-jiśrāêl łączy on przekaz o Toli z analogicznym tekstem o Szamgarze, który również jest nazwany wybawicielem Izraela $(3,31 b)$. Ponadto hebrajski rdzeń $j \check{s}^{\prime}$ (,wybawiać”, „ratować”, „wyzwalać”) sugeruje religijny i teologiczny aspekt aktywności sędziowskiej Toli, co również poza tradycją o Szamgarze - nie znajduje odpowiednika w tekstach o sędziach mniejszych. Pojawiające się w 10,1 imię Abimeleka podpowiada lektorowi, aby tekst o Toli czytał w bezpośrednim związku z przekazem o synu Gedeona. I ten szczegół nie znajduje równego sobie odpowiednika w analogicznych tekstach o lokalnych wodzach Izraela (3,31; 10,1-5; 12,8-15).

Analizowana kwestia budzi dużo kontrowersji egzegetycznych i rodzi zasadne pytanie o motyw, dla którego deuteronomista tak ściśle związał te tradycje. Motyw rzeczywistego czasowego następstwa raczej nie wchodzi tu w rachubę, ponieważ chronologia opisywanych zdarzeń nie odgrywa wiodącej roli ani w tej sekcji, ani w całej księdze. Odwołanie się do Abimeleka na tym etapie narracji winno być raczej odczytane w porządku logicznym i teologicznym aniżeli historycznym, choć formuła 'ahărê (,,po") w oryginalnym bloku tradycji 10,1-5; 12,8-15 z pewnością sugeruje także sekwencję chronologiczną. Próbując odkryć genezę i celowość tej literackiej więzi, niektórzy egzegeci sugerują edytorski zamiar połączenia cykli o Gedeonie, Abimeleku, Toli i Jairze $(6,1-10,5)$ w jedną spójną całość. ${ }^{17}$

17 S. Frolov, Judges, s. 188. 
Inni dopatrują się natomiast chęci podkreślenia wspólnego dla całej epoki - a więc rządów sędziów większych i mniejszych - problemu religijnej apostazji Izraela $i$ jego społeczno-politycznego rozbicia. ${ }^{18}$ W tym teologicznym kluczu tę część wiersza 10,1 interpretuje się najczęściej jako próbę przeciwstawienia dwu skrajnych modeli sprawowania władzy: prawego wyzwoliciela, zatroskanego o los uciśnionych rodaków (Tola), oraz podstępnego, cynicznego i krwawego króla (Abimelek). Formuła wajjākām 'ahărê 'ăbîmelek lehôšîa "et-jiśrāèl tôla ${ }^{\prime}$ (,,i powstał po Abimeleku dla wybawienia Izraela Tola”) sugerowałaby zatem nie tylko chronologiczne, ale i jakościowe następstwo, to znaczy początek nowej epoki charakteryzującej się diametralną zmianą w sposobie sprawowania władzy. Zgodnie z tą interpretacją, kolejny etap historii Izraela (czas Toli i Jaira) będzie upływał pod znakiem pokojowej egzystencji narodu wybranego i jego przywódców, której nie zakłóci żaden rozlew krwi czy intryga, jak to było w epoce Abimeleka.

Nieco więcej informacji na temat pochodzenia i miejsca społeczno-politycznych działań Toli daje dwustopniowa genealogia: ben-p $\hat{u}$ ' ben-dôdô 'îš jiśśăăkār (,syn Puy, syna Dodo, mąż z Issachara”10,1aß). Poza 10,1, imię Pua pojawia się w Lb 26,23 i 1Krn 7,1, gdzie mowa jest o synach Issachara, lecz w tych tekstach chodzi raczej o nazwę klanu aniżeli konkretne osoby. Trudno jest więc orzec czy informacje o przodkach Toli z 10,1 należy łączyć ściśle z imionami podanymi w Lb 26,23. Wszystko wskazuje na to, że krótka genealogia w 10,1 odnosi się do postaci historycznych, zaś teksty Lb 26,23 i 1 Krn 7,1 rekonstruują raczej dzieje klanów i rodów izraelskich. Niewiele światła na pochodzenie Toli rzuca imię jego dziadka: Dodo. W Biblii pojawia się ono dwukrotnie: w 2Sm 23,9 (por. 1Krn 11,12) określa ojca Eleazara, zaś w 2Sm 23,24 (por. 1Krn 11,26) pochodzącego z Betlejem ojca Elchanany. Eleazar i Elchanan byli wybitnymi dowódcami i bohaterami wojskowymi króla Dawida, tak więc ich

18 W. B l u e d o r n, Yahweh versus Baalism. A Theological Reading of the Gideon-Abimelech Narrative, JSOT.S 329, Sheffield Academic Press, Sheffield 2001, s. 275; T. B u t le r, Judges, WBC 8, Thomas Nelson, Nashville 2009, s. 257. 
ojców raczej nie można utożsamiać z rodzicielem Toli. Hebrajskie dôd zwykle tłumaczy się „,brat ze strony ojca”, „stryj” (LXX czyta: „krewny”) i wiąże z rdzeniem ,umiłowany", ${ }^{19}$ ale i ta etymologia imienia Dodo - związanego być może z okolicami Betlejem (2Sm 23,26; 1Krn 11,26) - niewiele wyjaśnia w kwestii pochodzenia ojca Toli. Mocniejsze światło na ten problem rzuca $\mathrm{z}$ kolei przyporządkowanie sędziego do rodu Issachara w 10,1a $\beta$. Jak wiadomo $z$ tekstów biblijnych: Rdz 46,13; Lb 26,23; 1Krn 7,1-2, najstarszy z czterech synów Issachara nosił imię Tola i od niego pochodził ród Tolaitów, który słynął z dzielnych wojowników, a w czasach Dawida gwarantował królowi kontyngent aż 22600 żołnierzy. To wszystko pozwala sądzić, że obecna w tradycji o Toli genealogia - zaczerpnięta przez redaktora z oryginalnego źródła o tym bohaterze (por. analogiczny przekaz w 12,13) - miała podkreślić jego duży prestiż społeczny przez wykazanie bezpośredniego związku z Tolaitami, potomkami Issachara, którzy na przestrzeni kolejnych pokoleń legitymowali się odwagą i walecznością. Okres wyzwolicielskiej misji i rządów sędziego Toli w historiografii Izraela staje się więc kolejną kartą dokumentującą przykładne oddanie i bohaterstwo tego hebrajskiego klanu.

Kolejnych trudności interpretacyjnych przysparza miejsca pobytu i społecznej aktywności sędziego. Według 10,1b, Tola mieszkał w Szamir w górzystej krainie Efraima. Niestety, na podstawie źródeł biblijnych niewiele da się powiedzieć na temat tej biblijnej miejscowości. Niektórzy badacze identyfikują Szamir z Samarią, ale tekst 1Krl 16,24 genezę nazwy Samaria wiąże wyraźnie z imieniem jej pierwotnego właściciela - Szemera i należącą do niego górą Szomron. Górę tę nabył monarcha Omri - założyciel jedynej dynastii królewskiej w północnym Izraelu - zabudował ją i założył miasto Samaria, nazywając je tak na cześć pierwotnego właściciela tej ziemi. Na bazie tych informacji należy sądzić, że stolica rządów sędziego Toli leżała

19 D. B 1 o c k, Judges, Ruth, NAC 6, Holman Publishers, Nashville 1999, s. 338; G. Mo o r e, A Critical and Exegetical Commentary on Judges, ICC, T. Clark, Edinburg 1895, s. 272. 
w innej części górzystego regionu Efraima. ${ }^{20}$ Biorąc pod uwagę odległość, jaką musiał przebyć sędzia pochodzący z północnego Kanaanu zasiedlonego przez Issachara, aby osiedlić się na terenie Gór Efraima, należy założyć, że miasto Szamir charakteryzowało się dużym prestiżem i miało strategiczne położenie, co umożliwiało skuteczne rządy w tym trudnym pod względem społeczno-politycznym regionie (por. 8,1-3; 12,1-7).

Nieco więcej danych summarium oferuje w kwestii władzy sprawowanej przez Tolę. Najpierw określa ją terminem jāša (,wyzwalać”, „wybawiać”, „przynosić ratunek”), podobnie jak w przypadku pokazywanych wcześniej sędziów większych $(2,16.18 ; 3,9.15 ; 6,14$ -15.36-37; 7,2.7; 8,22) i Szamgara $(3,31)$. Ten jeden z najbardziej rozpoznawalnych w teologii biblijnej czasownik, w wersie 10,1 zostaje dodatkowo wzmocniony czasownikiem qûm (,powstawać”, „stanąć”, ,przystąpić do walki”, „rozpocząć działanie”), który w księdze jest standardowym określeniem militarnej aktywności hebrajskich wyzwolicieli $(2,10.16 .18 ; 3,9.15 .20 ; 4,14 ; 5,7.12 ; 7,9.15 ; 8,20-21)$. Deuteronomista postrzegał więc aktywność Toli w tej samej kategorii działania zbawczego, co aktywność sędziów większych: Otniela, Ehuda, Debory i Baraka czy Gedeona. Na tym jednak kończy się opis wyzwolicielskiej misji Toli. W 10,1-2 brak jest jakichkolwiek teologicznych odniesień, typowych dla wyżej wymienionych charyzmatycznych wojowników, a przede wszystkim informacji o Bożym wybraniu, pomocy JHWH i w alce prowadzonej w obronie uciskanych Izraelitów. Brak teologicznej perspektywy w opisie rządów syna Puy należy tłumaczyć prawdopodobnie specyfiką źródła, z którego pochodzi summarium 10,1-2, a także optyką jego deuteronomistycznego redaktora. Obecność rdzenia jāša sugerująca zbawczy aspekt działań Toli kreuje jeszcze jeden istotny problem w perspektywie całego opisu jego społeczno-politycznej aktywności w Izraelu. I tak kontekst poprzedzający, czyli relacja o uzurpatorze Abimeleku (9,1-57), nie mówi nic o ucisku czy potrzebie wybawienia Izraela w epoce

${ }^{20}$ K. L aw s on Younge r, Judges and Ruth, NIVAC, Zondervan, Grand Rapids 2002, s. 237. 
Toli. Podobnie sama relacja o synu Puy (10,1-2) nie wskazuje na żadne zagrożenie zewnętrzne czy wewnętrzne, które domagałoby się wyzwoleńczej interwencji sędziego. W świetle sekcji 9,1-57 jedynym wyjaśnieniem tej kwestii byłaby ewentualna konieczność zażegnania społeczno-politycznego chaosu, w jakim Izrael pogrążył się w następstwie wojny domowej między Abimelekiem a Sychemitami. Ale czy o taką interwencję chodziło deuteronomiście włączającemu przekaz o Toli w sekwencję relacji o Gedeonie i Abimeleku? A może chciał on tylko wyróżnić Tolę z spośród pięciu przywódców, o których opowiada w 10,1-5; 12,8-15, aby nadać mu wyższy status społeczny? Nie można też wykluczyć, że redaktor księgi odwołuje się tu do jakiegoś innego źródła opowiadającego o wyzwoleńczych działaniach Toli, które nie znajduje odzwierciedlenia w innych częściach Biblii, albo za pomocą tej specyficznej terminologii postanowił zaznaczyć nieprzerwaną sukcesję wyzwolicieli w przedmonarchicznych dziejach Izraela. Z uwagi na brak źródeł trudno jest znaleźć rozwiązanie tych kwestii. Jedno jednak wiadomo. Dzięki tej teologicznej glosie Tola urasta do rangi wyjątkowej figury wśród sędziów mniejszych.

Przynależność do tej grupy liderów Izraela podkreśla ostatnie pojęcie określające jego publiczną aktywność, a mianowicie typowy dla księgi i wspomniany wyżej rdzeń špṭ. Termin šāpaṭ nie wskazuje w kontekście tradycji o sędziach mniejszych na nic szczególnego, podobnie zostaje określona zdecydowana większość wodzów i wyzwolicieli w epoce przedmonarchicznego Izraela $(3,10 ; 4,4 ; 10,2.3$; 12,7.8-9.11.13-14; 15,10; por. 1Sm 4,18; 7,15-17). Na uwagę zasługuje raczej długość rządów wyrażonych tym pojęciem, która opiewa na dwadzieścia trzy lata. Prócz Jaira, który dzierżył analogiczną władzę przez okres dwudziestu dwu lat $(10,3)$, żaden z sędziów mniejszych nie może poszczycić się tak długo sprawowanym urzędem. W teologicznej perspektywie księgi (por. 8,28), kilkudziesięcioletnie rządy były uważane za ewidentny znak Bożego błogosławieństwa i życzliwości. W związku z tym długie panowanie Toli i Jaira można byłoby odbierać jako teologiczną ilustrację ich religijnej poprawności i wysokiego społeczno-politycznego autorytetu. Niestety, źródło zredagowane przez deuteronomistę w 10,1-2 nie udziela żadnych 
dodatkowych informacji w tej materii. Brak symbolicznej krągłości liczby dwadzieścia dwa (por. liczby 7, 20 i 40 używane w księdze w podobnym kontekście) można byłoby odczytać natomiast jako argument przemawiający za historyczną wiarygodnością podawanej $\mathrm{w}$ summarium informacji. Stoi ona w ewidentnym kontraście do danych liczbowych przywoływanych w przypadku sędziów większych, które uderzają wysokością i teologiczną symboliką (por. 3,11.30; 5,31; $8,28)$.

Ostatni fragment summarium w sposób typowy dla wszystkich tradycji o sędziach mniejszych w sekcjach: 10,1-5 i 12,8-15 kończy się informacją o śmierci Toli i pogrzebie, który odbył się w stolicy jego rządów - Szamirze (10,2b). Ten passus nie wymaga osobnego komentarza. Można tylko dodać, że w teologicznej strukturze deuteronomistycznej historiografii Izraela (Joz-2Krl) tak opisane zamknięcie rządów, czyli sekwencja informacji traktujących kolejno o życiu, śmierci i miejscu pochówku bohatera, jest zwykle formą wyrazu prawdy o ich pokojowym i praworządnym charakterze.

\section{Najważniejsze kwestie egzegetyczne tradycji o Jairze (10,3-5)}

Zgodnie z podjętymi na wstępie założeniami badawczymi, kolejny akapit artykułu zaprezentuje zwięzłą analizę egzegetyczną summarium o Jairze (10,3-5), które rozpoczyna się typową dla sekcji 10,1-5 formułą wajjākām 'ahărājww (,,i powstał po nim”-10,3a; por. 10,1a). Jeśli chodzi o strukturę literacką tego passusu, to przypomina ona pozostałe relacje o sędziach mniejszych (10,1-2; 12,8-15). Po formule otwierającej ten zwięzły kronikarski zapis, która łączy go z poprzedzającym przekazem o Toli, pojawiają się kolejno informacje o długości rządów $(10,3 b)$ oraz śmierci i pogrzebie Jaira $(10,5)$. Tym, co wyróżnia źródło o Gileadczyku opracowane przez deuteronomistę, jest jego centralna część poświęcona licznemu potomstwu i dużej zamożności bohatera $(10,4)$, która przesądza o specyfice tego przekazu. Tradycja o Jairze pod względem literackim jest materiałem literackim opartym na ustnym lub pisanym źródle zredagowanym przez deuteronomistycznego edytora księgi i utrwalonym w formie 
krótkiej noty biograficznej. W porównaniu z na wskroś teologicznymi opracowaniami o sędziach większych, tekst o Jairze nie mający żadnych odniesień natury teologicznej mógłby sugerować znacznie większy stopień wiarygodności historycznej. Z uwagi na brak możliwości konsultacji tych źródłowych tradycji, trudno się jednak wypowiadać w tej materii. Aktualna treść i forma przekazu o Toli (por. teksty o Ibsanie i Abdonie w 12,8-10.13-15), która odbiega od struktury i charakteru innych tekstów zredagowanych przez deuteronomistę w Księdze Sędziów, mogłaby też sugerować, że wiersze 10,3-5 dość wiernie zachowały charakter pierwotnego źródła. Źródło to jeszcze przed włączeniem do księgi mogło już mieć kształt pisanego przekazu funkcjonującego w regionie Gileadu zarządzanego przez Tolę. Oczywiście wnioski tego rodzaju mają wartość jedynie hipotezy badawczej, którą trudno zweryfikować z uwagi na brak dostępu do oryginalnych źródeł, ale są w pewnej mierze potwierdzone przez treść i formę aktualnych tekstów biblijnych. Chodzi tu szczególnie o schematyczną notę o licznym potomstwie przywódcy, które piastuje władzę nad całym regionem $(10,4$; por. $12,9.14)$.

Jako jeden z nielicznych tekstów księgi, passus o Toli nosi na sobie ewidentny ślad pracy redakcyjnej, który zostawił deuteronomista. Opisując w wierszu 10,4b bogactwo potomków Jaira - czyli trzydzieści miast w Gileadzie - mówi, że były one zwane „osiedlami Jaira", i że ta wyjątkowa nazwa przetrwała aż do czasów jemu współczesnych. Ta szczególna adnotacja jest swoistą wizy tówką deuteronomistycznego historiografa odpowiedzialnego za ostateczny kształt kompleksu ksiąg Joz-2Krl (por. Joz 4,9; 5,9; 6,25; 7,26; Sdz 1,21; 6,24; 15,$19 ; 18,12 ; 1 \mathrm{Sm} 5,5 ; 6,18 ; 8,8$ itd.).

Bliźniacza w stosunku do przekazu o Toli (por. 10,1a) struktura sceny otwarcia relacji o Jairze (10,3a) daje lektorowi księgi do zrozumienia, że obie postacie i prezentowany przez nie model władzy należy rozumieć łącznie jako jedną historyczną rekonstrukcję tej samej epoki w dziejach Izraela. ${ }^{21}$ Tak jak Tola następował po Abimeleku, tak sukcesorem misji wyzwoleńczej i władzy sędziowskiej syna Puy

21 S. Frolov, Judges, s. 188. 
był Jair, którego hebrajskie imię (jā'îr) można oddać zawołaniem: „oby [Bóg] oświecił”; „niech [Bóg] oświeci”. W tej fazie narracji dość istotną wydaje się informacja o pochodzeniu Jaira. Sędzia wywodził się z Gileadu, co już na tym etapie zapowiada historię Jefte, który obok proroka Eliasza jest najbardziej znanym Gileadczykiem w Biblii $(11,1)$. W porównaniu $\mathrm{z}$ tekstem o Toli, redaktor źródła o Jairze nie skupił się na pochodzeniu bohatera. W wierszu 10,3 brakuje imienia ojca sędziego i imion jego przodków, nie ma też informacji na temat rodu, z którego się wywodził (por. 10,1). Być może te szczegóły zaginęły w trakcie procesu przekazu tradycji o Jairze, ${ }^{22}$ choć bezpieczniej jest założyć, że genealogia nie wchodziła w standardowy obręb oryginalnych przekazów o sędziach mniejszych i znalazła się tylko w 10,1 (por. 12,13). Deuteronomistyczny redaktor źródła o Jairze zupełnie pomija wszystkie biograficzne szczegóły z nim związane, wspominając tylko, że ojczyzną sędziego był Gilead, czyli region Transjordanii położony na wschód od Jordanu, między Jeziorem Tyberiadzkim a Morzem Martwym. Na bazie materiału źródłowego, na którym redaktor deuteronomistyczny opiera tę sekcję księgi (10,3-12,7), można byłoby przypuszczać, że w epoce Jaira Izraelici wciąż toczyli o Gilead walki z Ammonitami. Walki te ciągnęły się od epoki Mojżesza (11,13-28) aż po okres rządów pierwszego króla Izraela - Saula (1Sm 11,1-15). I choć summarium 10,3-5 nie wspomina o nich, to jednak

22 R. B o li n g, Judges, s. 186, 188. Imię Jair pojawia się w kilku kontekstach biblijnych. Zgodnie z Lb 32,41; Pwt 3,14; 1Krl 4,13, Jair jest synem Manassesa, syna Jakuba, który podbił region Argob (Baszan) w Gileadzie, a zdobyte miejscowości nazwał „osiedlami Jaira”. Z kolei 1Krn 2,22-23 mówi o tym, że ojcem Jaira był Segub, syn Chesrona i córki Makira, czyli ojca Gileada. Jair miał dwadzieścia trzy miasta w ziemi Gilead oraz „osiedla Jaira i Kenat”, które zabrał Aramowi i krajowi Geszur z przynależnymi miejscowościami w łącznej liczbie sześćdziesięciu. Wszystkie te lokalizacje należały do synów Makira. Na związek tych tradycji z tekstem o Jairze z 10,3-5 mógłby wskazywać stały wątek hawwōt jā' $\hat{\imath} r$, „osiedli Jaira”, czyli miejsc (miast) w Gileadzie. Wszystko jednak wskazuje na to, że tylko w Sdz 10,3 chodzi o postać konkretnego bohatera. W pozostałych kronikarskich tradycjach Biblii imię jâ'îr ma sens kolektywny i odnosi się do klanu wywodzącego się od Jaira, syna Manassesa, który żył w epoce hebrajskich nomadów podbijających i zasiedlających tereny Zajordania. 
tworzą one tło historyczne dla obszernej relacji o Gileadczyku Jefte $(10,8-11,40)$, którego dzieje deuteronomista wiąże z epoką Jaira $(10,6) .{ }^{23}$

Jak wynika z treści 10,3 (por. Lb 32.41; Pwt 3,14; 1Krl 4,13), Jair był Gileadczykiem należącym do rodu Manassesa, który sprawował władzę nad tym regionem przez dwadzieścia dwa lata. Ten długi okres rządów wzmocnił pozycję jego klanu na tym terenie do tego stopnia, że Jair zdołał rozciągnąć wpływy na okoliczne osiedla i miasta Gileadu. Ta informacja jest najważniejszą w historii tego sędziego prezentowanej przez deuteronomistę. Nota o wyjątkowej liczbie jego synów i zajmowanych przez nich miejscowościach leży w centralnej części summarium i stanowi o jego tematycznej specyfice. Według 10,4, o sile rodu Jaira decydowała liczba męskich potomków i zakres sprawowanej przez nich władzy. Narrator wspomina aż o trzydziestu synach, z których każdy dominował nad jednym miastem regionu i nosił się jako jego przywódca, czego dowodem jest wymowny w tamtej epoce zwyczaj dosiadania oślęcia, prawdopodobnie zarezerwowany dla przedstawicieli ówczesnej lokalnej arystokracji. Synom Jaira autor summarium przypisuje społeczno-polityczną kontrolę w Gileadzie. Tekst biblijny milczy na temat genezy i charakteru tej władzy. We wszystkich tradycjach o sędziach większych rządy wyzwolicieli są następstwem ich zwycięskiej walki zbrojnej. Na taką ewentualność mógłby wskazywać klimat wojny z Filistynami i Ammonitami w Gileadzie opisany w najbliższym kontekście następującym (10,6-18; 11,1-40), jednakże summarium o Toli ani żaden przekaz w sekcjach 10,1-5 i 12,8-15 nie wspomina wprost o militarnej aktywności bohaterów. Jeśli zatem weźmie się pod uwagę pokojowy kontekst tradycji o sędziach mniejszych, tak mocno podkreślany przez deuteronomistycznego redaktora księgi, to nie można wykluczyć możliwości, że rządy synów Jaira były owocem politycznych zabiegów i wpływów opartych

${ }^{23}$ Bliskość tradycji o Jairze (10,3-5) i Jefte (10,6 - 12,7) w Księdze Sędziów, dodatkowo sygnalizowana przez treść wiersza 10,6, nie przesądza oczywiście o chronologicznej jedności (następstwie) tych epok, ale też jej nie wyklucza. Tradycje te z pewnością łączy jedność topograficzna, obie dotyczą regionu Gileadu, w którym w tym okresie sytuacja historyczna zmieniała się dość dynamicznie. 
na rodzinnych koligacjach i zależnościach społeczno-gospodarczych w regionie Gileadu. Niestety, brak źródeł nie pozwala na wiarygodne rozstrzygnięcie tej kwestii i zmusza do pozostania w sferze domysłów.

Wiersz 10,4b mówi o trzydziestu ośrodkach władzy zwanych hawwot jā' $̂$ r („,osiedlami Jaira”). TM i LXX ${ }^{\mathrm{B}}$ wiążą ich nazwę z polityczną aktywnością trzydziestu potomków Jaira, tylko LXX ${ }^{\mathrm{A}}$ formułą: ekalesen autas („,nazwał je”) przypisuje ich genezę samemu Jairowi. Trudno jest sprecyzować wielkość i społeczno-polityczną specyfikę tych osiedli. Niektóre teksty źródłowe wskazują na namiotowe obozy półnomadów, a więc okresowe lub stałe ośrodki koczownicze, które Jair - rozumiany w tym kontekście raczej jako klan aniżeli potomek wywodzący się od Manassesa - odbił Amorytom (Lb 32,41; Pwt 3,14). Inne tradycje biblijne mówią wprost o miastach i przynależnych do nich osiedlach peryferyjnych, które należały do klanu Jaira w Gileadzie (1Krn 2,22-23). Wiarygodność noty o trzydziestoosobowym gronie synów Jaira i ich lokalnej władzy nad trzydziestoma miastami Gileadu budzi niemałe kontrowersje już na poziomie tekstu biblijnego. I tak LXX podaje liczbę trzydziestu dwu synów i miast Jaira, a 1Krn 2,22 opowiada o dwudziestu trzech miastach. W kontekście innych tradycji o sędziach mniejszych $(12,9.14)$ można przypuszczać, że okrągła liczba „trzydzieści” ma walor symbolu obrazującego zasobność i pozycję społeczną charakterystyczną dla arystokratycznego (królewskiego) rodu, choć tekst natchniony nie czyni w tym względzie żadnej aluzji. Fakt, że każde z miast jest opisane jako własność (dziedziczna?) synów Jaira i nosi tę samą nazwę (hawwōt jā' îr -,,osiedla”, „miasta Jaira”), sugeruje, że sędzia podzielił zdobyte przez siebie albo wcześniej przez klan ojca (por. Lb 32,41; Pwt 3,14) tereny między trzydziestu swych męskich potomków, lub też stał się z czasem przywódcą konfederacji (unii) trzydziestu miast (osiedli) Gileadu (por. 1Krl 4,13; 1Krn 2,22). Tak duża liczba potomstwa zakłada znaczną liczbę żon (por. 8,30), co w kontekście tradycji biblijnych i bliskowschodnich stanowi kolejny dowód na ekonomiczną zasobność sędziego.

Kontrowersji interpretacyjnych przysparza również informacja o tym, że synowie Jaira dosiadali trzydziestu ośląt, ponieważ 
precyzyjne znaczenie tego zwyczaju jest w dużej mierze enigmatyczne. Z pewnością autor źródła i jego deuteronomistyczny redaktor chcieli w ten sposób podkreślić wysoką pozycję społeczną i bogactwo potomków Jaira. Dość bliski dla wiersza 10,4 kontekst, jakim jest pieśń Debory (5,1-31b), podkreśla społeczny autorytet i godność tych, którzy dosiadają białych oślic i zasiadają na kobiercach $(5,10)$. Oślica (mulica) była tradycyjnym (rytualnym) środkiem transportu podczas królewskiej koronacji w epoce Dawida i Salomona (1Krl 1,33.38), była też zwierzęciem, z którego korzystali królowie, bogaci obywatele i możnowładcy, by podkreślić swój splendor i godność $(1,14 ; 1 \mathrm{Sm} 25,20 ; 2 \mathrm{Sm} \mathrm{17,23;19,26;} \mathrm{Za} \mathrm{9,9;} \mathrm{por.} \mathrm{2Sm} \mathrm{13,29;} \mathrm{18,9,}$ Rdz 49,11; Mt 21,5; Łk 19,30). ${ }^{24} \mathrm{~W}$ kontekście przekazu o Jairze i jego synach obraz trzydziestu mężczyzn dosiadających trzydziestu oślic i przemierzających należące do nich trzydzieści miast Gileadu jest symbolem i ewidentnym dowodem dostatku, pokoju i pomyślności, w jakich żył klan sędziego. Można się tylko zastanawiać, dlaczego na określenie osła wybrano tu pojęcie 'ajir, a nie bardziej popularne w Biblii słowo hămôr. Prawdopodobnie wybór ten został podyktowany względami retorycznymi. Warto bowiem zwrócić uwagę na pokrewieństwo brzmienia, jakie w ten sposób rodzi się między kolejnymi terminami w 10,4: 'ajir („,oślę”, „osiol”), 'îr („,miasto”) i Jā' îr (imię sędziego), oraz na regularną rytmikę przekazu. ${ }^{25}$

Ostatnia informacja na temat Jaira dotyczy miejsca jego pochówku w Kamon, o czym, zgodnie ze strukturą tego typu summariów, opowiada ostatni wiersz tradycji biblijnej $(10,5)$. Niektórzy egzegeci identyfikują Kamon z Qamm (Tell-Qaimun) albo z biblijnym Jokneam (Joz 12,22) usytuowanym między Jeziorem Tyberiadzkim a Ramot w Gileadzie. ${ }^{26}$ Treść noty o śmierci i pochówku Jaira można uważać

24 A. M a $1 \mathrm{a} \mathrm{m}$ a t, Mari and the Early Israelite Experience, Oxford University Press, Oxford 1989, s. 2-4, 80; G. M o o r e, Judges, s. 273.

${ }_{25}$ R. B oling, Judges, s. 188; K. L a w s on Younge r, Judges and Ruth, s. 239.

26 H. Th o m p s o n, Kamon, w: D. Fr e e d m a n (red.), Anchor Bible Dictionary, t. IV, New York 1992, s. 5. 
za argument przemawiający za pokojowym wymiarem rządów Gileadczyka i jego naturalnym zgonem, ${ }^{27}$ ale jednocześnie trzeba wziąć pod uwagę fakt, iż w podobny sposób kończą się wszystkie komponenty sekcji 10,1-5; 12,8-15, co sugerowałoby, że taki epilog był stałym literackim standardem tradycji o sędziach mniejszych (por 10,2; 12,10.12.15). Podobne zakończenie (analogiczna formuła: wajjāmot $N$ wajjiqqābēr - ,i umarł N i z ostał pogrzebany”) zawierają też teksty o sędziach większych: Gedeonie $(8,32)$ i Jefte $(12,7)$.

\section{Przesłanie teologiczne tradycji o Toli i Jairze (10,1-5)}

Zwięzłe summaria o Toli i Jairze, które tworzą pierwszą odsłonę dwuetapowej sekcji poświęconej pięciu sędziom mniejszym (10,15; 12,8-15), wprowadzają nową jakość do księgi, ponieważ dodają alternatywną, a zarazem uzupełniającą listę izraelskich wodzów i wyzwolicieli przedmonarchicznego Izraela. Literacka i teologiczna specyfika tych krótkich anegdot kreuje zupełnie inny pod wieloma względami obraz izraelskiego sędziego i stoi w wyraźnej opozycji do standardów, według których zostały zredagowane teksty o Otnielu, Ehudzie, Deborze i Baraku, Gedeonie, uzurpatorze Abimeleku, Jefte i Samsonie. Poza Szamgarem $(3,31)$ - i być może Tolą $(10,1)$ sędziowie mniejsi nie wyzwalają rodaków z ucisku, nie muszą też, jak Gedeon (6,25-32), walczyć z przejawami religijnej apostazji czy borykać się z konsekwencjami zwyczajowej inkulturacji w Izraelu. Opierając się na treści biblijnych sekcji 10,1-5 i 12,8-15, można przypuszczać, że sędziowie mniejsi nie angażowali się w kwestie związane z religią, zwyczajami czy rodzimym prawem. Sprawowali rządy wzorowane, przynajmniej po części, na społeczno-politycznym modelu obowiązującym wówczas w Kanaanie (konfederacje państw-miast) w podległych im lokalnych społecznościach, troszcząc się o ich doczesny dobrobyt oraz o umocnienie własnych wpływów. Dowodem na to może być motyw licznego potomstwa podkreślany regularnie przez teksty biblijne $(10,4 ; 12,9.14)$. Jak wiadomo, dawało

27 D. B 1 o c k, Judges, Ruth, s. 340. 
ono możliwość małżeńskich koligacji i było gwarantem społecznej siły w ówczesnych strukturach pokoleniowych.

Przekazy o Toli i Jairze pokazują epokę przedmonarchiczną zupełnie $\mathrm{z}$ innej strony aniżeli inne źródłowe partie księgi. Zgodnie $\mathrm{z}$ deuteronomistyczną wizją zaprezentowaną $\mathrm{w} 10,1-5$, jest to czas materialnego i społeczno-politycznego rozkwitu, którego nie zakłócają ani religijne odstępstwa i wewnętrzne waśnie Izraelitów, ani długotrwały ucisk ze strony sąsiednich ludów. W przeciwieństwie do opisanych przez deuteronomistę sędziów większych, Tola ${ }^{28}$ i Jair nie muszą więc zrzucać jarzma niewoli, tylko pełnić władzę administracyjno-prawną. Obaj sędziowie nie pochodzą z największych i najlepiej zorganizowanych pod względem ekonomicznym i militarnym pokoleń Izraela. Ich rodowód, a w związku z tym zakres władzy i status społeczny, należy wiązać z mniej licznymi i niezamożnymi rodami Izraela, takimi jak: Issachar $(10,1)$ i Manasses $(10,3-4$; por. Lb 32,41; Pwt 3,14; 1Krl 4,13), które zamieszkiwały górzyste tereny Efraima i Gileadu wraz z groźnymi i nieprzyjaznymi Moabitami, Ammonitami i Edomitami $(10,3 ; 12,7)$. W opinii deuteronomisty, która zrodziła się na bazie analizy dostępnych mu źródeł, obaj sędziowie byli kompetentnymi i zaradnymi włodarzami swych małych ojczyzn stojącymi przez okres pięćdziesięciu pięciu lat na straży praworządności i pokoju $(10,2.3)$. Wyraźnym profilem dwu tradycji zaprezentowanych w 10,1-5 jest zupełny brak kolorytu religijnego, czyli nieobecność jakichkolwiek odniesień do Boga oraz religijno-kultycznych postaw hebrajskich przywódców i rządzonego przez nich ludu. Fakt ten można tłumaczyć literacką specyfiką źródeł, z których korzystał deuteronomista, ale też jego świadomą i zamierzoną optyką redakcyjną. W kluczu tej optyki Tola i Jair, oraz podobni im lokalni przywódcy, jawią się jako skuteczni gwaranci wolności, bezpieczeństwa i dostatku, tak w okresie zagrożenia (10,1; por. 3,31$)$, jak i pokoju (10,3-5; por. 12,8-15). Figury sędziów mniejszych mogą być

28 Jak wskazano wyżej, odniesiona do Toli treść formuły: l`hôšîa "et-jiśrāêel ma wymiar wyłącznie teologiczny i literacki, wskazujący na więź wierszy 10,1-5 z wcześniejszymi sekcjami księgi (3,31; 6,1 - 9,57). 
odbierane jako alternatywny wzorzec sprawowania władzy w Izraelu, który w księdze jest przeciwstawiony modelowi silnego $i$ ambitnego militarno-politycznego przywódcy wywodzącego się z najpotężniejszych, a zarazem najbardziej nastawionych na ekspansję hebrajskich rodów. Zgodnie z deuteronomistyczną wizją epoki przedmonarchicznej były nimi: Efraim, Beniamin i Juda. Zaplecze militarne i polityczne, jakim szczycili się przywódcy tych pokoleń, było dla nich realną pokusą, aby nie liczyć się z prawami i potrzebami słabszych klanów (por. 5,14-18; 6,25-32; 8,1-3.35; 9,1-57; 11,1-11; 19,1-21,25), a po zwycięstwie nad wrogiem narzucić im nieuprawnioną dominację (8,1-3; 12,1-6; 19,1-21,25), która sprzeciwiała się systemowi społecznej równości i solidarności wiązanym przez deuteronomistę z teokracją epoki Mojżesza i Jozuego.

Figury Toli i Jaira, czyli lokalnych przywódców realizujących społeczno-polityczną misję na podległym sobie terenie - zgodnie z deuteronomistyczną rekonstrukcją epoki przedmonarchicznejjawią się jako pożądany w Izraelu wzorzec rządów. ${ }^{29}$ Mocno akcentowane w drugiej części księgi oczekiwanie na instytucję króla $(17,6 ; 18,1 ; 19,1 ; 21,25)$, jest w pewnej mierze uwarunkowane realiami sprawowania władzy reprezentowanymi przez sędziów mniejszych, które deuteronomista znał z dostępnych sobie źródeł. Chodzi o figurę kompetentnego i doświadczonego lidera, który potrafi walczyć o niepodległość (10,1; por. 3,31), ale całą swą energię angażuje w mądre i pokojowe rządy, które zapewniają podległej mu społeczności spokojne i dostatnie życie oraz polityczno-militarną stabilność (10,4; por. 12,9.14). Waga tego problemu przybiera szczególnie na sile, gdy weźmie się pod uwagę akcentowane przez deuteronomistę następstwo rządów Toli i Abimeleka, które są dla siebie ewidentnym przeciwieństwem. W świetle anarchii i wojny opisanej w 9,1-57, przekaz o Toli i Jairze (10,1-5) jawi się jako powrót do praworządnej i sprawiedliwej

29 P. M c N u t t, Reconstructing the Society of Ancient Israel, Westminster J. Knox Press, Louisville 1999, s. 99-101; G. M e n d e $\mathrm{n}$ h a 11, The Relation of the Individual to Political Society in Ancient Israel, w: J. M ye r s (red.), Biblical Studies. FS. H. Alleman, The Judaica Press, New York 1960, s. 89-108. 
władzy mającej na celu dobro Izraela, a nie własne polityczne ambicje i partykularne przywileje.

Pozytywny wymiar rządów Toli, Jaira i podobnych im lokalnych wodzów Izraela $(3,31 ; 12,8-15)$ jest jeszcze bardziej oczywisty w perspektywie teologii deuteronomistycznej prezentowanej w sekcji programowej księgi $(2,1-3,6)$ i powracającej na różny sposób w tekstach o sędziach większych $(2,11 ; 3,7.12 ; 4,1 ; 6,1 ; 10,6 ; 13,1)$. W jej kontekście brak odniesień do Boga w 10,1-5 (por. 3,31; 12,8-15) nie musi wcale oznaczać apostazji czy religijnego kryzysu, o których deuteronomista mówi zawsze wprost i przy użyciu specjalnej terminologii (bałwochwalstwo ujmowane za pomocą idei służby obcym bogom). Równie dobrze może oznaczać wielokrotnie opisywaną w kompleksie ksiąg Joz-2Krl pokojową codzienność Izraela, kiedy to Boże błogosławieństwo i łaskę gwarantuje sprawiedliwość i bogobojność wodza, z którymi idzie w parze wierność poddanych (Joz 1,1-18; $1 \mathrm{Sm}$ 7,2-17; 14,47-52; 2Sm 5,1-10,19; 1Krl 3,1-10,29). Pośrednim wskazaniem na Bożą obecność zbawczą na tym etapie dziejów Izraela jest inicjująca przekaz o Toli hebrajska formuła lehôšîa 'et-jiśrāêl (,dla zbawienia Izraela /aby wybawić Izraela" - 10,1; por. 10,13; 13,5), która w innych miejscach księgi ilustruje aktywność JHWH lub wyzwoleńczą działalność powołanego przez Niego charyzmatyka. Jej sens oraz teologiczny wymiar aktywności urzędu sędziego wyrażony hebrajskim šâpat, stawiają Tolę w jednym szeregu z pozostałymi wezwanymi przez Boga wyzwolicielami. Naprawczy (wyzwoleńczy) aspekt działań Toli sugeruje również kontekst poprzedzający (9,1-57). Zgodnie z deuteronomistyczną wizją epoki przedmonarchicznej, rządy Toli mogą być odczytane jako przywrócenie pokoju i stabilności politycznej w Izraelu po bratobójczej wojnie wywołanej przez spór Abimeleka z Sychemitami. ${ }^{30} \mathrm{~W}$ aktualnej teologicznej optyce księgi Tola i Jair stają na straży praworządności i pokoju w Izraelu,

30 T. B r e n s in ge r, Judges, BCBC, Herald Press, Scottdale 1999, s. 116; D. B 1 o c k, Judges, Ruth, s. 337-338; Y. A m i t, Judges. Introduction and Commentary, BCI, Mikra Leyisra'el, Tel Aviv 1999, s. 43. 
przyczyniając się do odrodzenia porządku społecznego zachwianego przez syna Gedeona $(9,1-57)$.

Według podobnych kryteriów metodologicznych można sprecyzować i zinterpretować teologiczny sens tradycji o Jairze (10,3-5). Jej aktualna biblijna wersja to owoc pracy deuteronomistycznego edytora księgi bazującego na źródłach, których forma i treść jest dziś trudna do odtworzenia. Zgodnie z teologiczną wizją deuteronomisty, Jair był pierwszym z sędziów mniejszych, który nie realizował misji wybawienia Izraela (por. 3,31; 10,1), czyli nie musiał stawać na polu walki. W przeciwieństwie do sędziów większych i Toli (por. 10,1a), Jair nie jest pokazany jako wyzwoliciel, który najpierw kładzie kres uciskowi swego ludu, a potem sprawuje władzę mocą zdobytego autorytetu społecznego i militarnego. Deuteronomistyczna rekonstrukcja jego rządów nie odwołuje się do wątku (nie)wierności religijnej Izraela czy zbawczej obecności JHWH, przez co zarysowany w niej obraz sędziego nie ma cech charyzmatyka, który działa z mandatu Bożego i Jego mocą. Władza Jaira jest skoncentrowana na administracyjnym zarządzaniu podległym mu terenem i społecznością, które ma na celu stworzenie odpowiednio ugruntowanej bazy ekonomicznej i politycznej dającej gwarancję długoterminowego i skutecznego wpływania na przyszłość regionu. Zgodnie z przekazem biblijnym, najważniejszym sukcesem Jaira było stworzenie silnego rodu, który - przez odpowiednio prowadzoną politykę i koligacje małżeńskie - stwarzał możliwość przejęcia kontroli nad ośrodkami miejskimi Gileadu. W oparciu o treść sekcji 10,3-5 i 12,8-9.13-14 można założyć, że tak rodziły się podwaliny potężnych hebrajskich rodów, które potem usiłowały sięgać po władzę monarchiczną w epoce Samuela (1Sm 8 - 2Sm 5). Nie ulega bowiem wątpliwości, że o statusie instytucji króla w Izraelu zadecydowały w dużej mierze wzorce obowiązujące w strukturach miast-państw Kanaanu, które od autochtonicznych społeczności Izraelici czerpali już w dobie rządów Gedeona, Abimeleka, Jaira, Ibsana i Abdona. W ten społeczno-polityczny nurt przemian weszli Saul (1Sm 9-31) i Dawid (2Sm 1-24; 1Krl 1-2), którym udało się stworzyć trwałe podstawy władzy królewskiej będące w stanie oprzeć się wewnętrznym i zewnętrznym naciskom 
politycznym i militarnym. Struktury lokalnej władzy stworzone przez Jaira i kolejnych sędziów mniejszych (12,8-10.13-15) nie posiadały jeszcze takiej mocy i efektywności. Idąc za narracyjnym wątkiem księgi należy sądzić, że trzydziestu potomków sędziego Jaira i zarządzane przez nich osiedla straciły swą polityczno-militarną rolę w chwili ataku Ammonitów (por. 10,6-9). W konfrontacji z dobrze uzbrojonym i zorganizowanym najeźdźcą te niedoświadczone i kruche struktury oparte na prawie własności, więzach pokrewieństwa i bilateralnych przymierzach kolejny raz okazały się zbyt słabe. Do takiego wniosku prowadzi deuteronomistyczna rekonstrukcja tamtych zdarzeń (por. 10,6-11,40), która opowiada, że lud i wodzowie Gileadu w obliczu ammonickiej agresji nie zwrócili się o pomoc do synów Jaira, lecz szukali ratunku u Jefte, charyzmatycznego wodza znanego z męstwa i brawury $(10,17-18 ; 11,8)$. Barwna scena otwierająca narrację o synu Gileada $(10,17-11,11)$ nosi bowiem znamiona świadomie przepracowanego źródła i podaje deuteronomistyczną ocenę ówczesnej sytuacji historycznej. Zgodnie z tą oceną należałby sądzić, że administracyjno-rozjemcze narzędzia władzy sędziów mniejszych oraz stworzone przez nich militarne i społeczno-polityczne struktury sprawdzały się tylko w okresie pokoju, zaś w przypadku zewnętrznego zagrożenia były nieefektywne.

Problematyka odpowiedniego systemu rządów dla Izraela jest motywem wiodącym nie tylko tej sekcji księgi, ale też jej epilogu (17,121,25), a swe dopełnienie znajduje w deuteronomistycznym opisie narodzin monarchii $(1 \mathrm{Sm} 7,2-12,25)$. W tym kontekście odmienne pod względem źródłowym, literackim i teologicznym tradycje o Gedeonie, Toli, Jairze i Jefte stają się dla deuteronomisty dobrą okazją, aby zaprezentować odmienne wzorce władzy, które z różnym skutkiem funkcjonowały w dynamicznie zmieniających się realiach epoki sędziów. Zgodnie z jego koncepcją, zarówno pokojowe rządy Toli i Jaira, które zaowocowały lokalnymi strukturami władzy opartymi na licznym potomstwie, więzach klanowych i własności ziemskiej, jak i opisana po nich militarna i społeczno-polityczna aktywność charyzmatycznego wodza Jefte, który osiągnął sukces bez poparcia własnego rodu $(10,6$ - 12,7), jawią się jako istotne etapy społecznego 
rozwoju hebrajskich pokoleń w perspektywie nieodległych narodzin władzy królewskiej w Izraelu.

W aktualnej strukturze księgi teksty o rządach Toli i Jaira $(10,1-5)$ stanowią tło historyczne i teologiczne dla dziejów Jefte, które toczą się na tych samych terenach Gileadu i Zajordania, ale w odmiennej scenerii religijnej i politycznej, zdominowanej przez ponowną apostazję Izraela i inwazję ammonicką. Specyfikę tej sytuacji, a nade wszystko destruktywne skutki niewiary Izraelitów deuteronomista pokazuje za pomocą zamierzonego kontrastu narracyjnego, świadomie zestawiając ze sobą przekazy o pokojowych i pomyślnych rządach Toli i Jaira z opisem prześladowania Ammonitów. Zgodnie z przyjętą $w$ księdze optyką teologiczną, te pierwsze sugerują ład społeczny wynikający z łaskawości JHWH uwarunkowanej poprawną pod względem religijnym i społeczno-kulturowym postawą ludu. Z kolei ten drugi funkcjonuje jako kolejna literacka ilustracja konsekwencji cyklicznych odstępstw kultycznych w okresie przedmonarchicznym, które sprowadzały na hebrajskie pokolenia długi i upokarzający ucisk oraz społeczny chaos i anarchię. To dlatego sędzia Jefte będzie musiał stawić czoło najpierw groźnym Ammonitom, a potem siłą i bezwzględnością jednoczyć skłócone ze sobą i pogrążone w walce o władzę klany, które zabiegają o własne interesy polityczne nie tylko w chwili zagrożenia, ale i triumfu (11,1-11;12,1-6).

ks. Dariusz DZIADOSZ

Słowa kluczowe: Tola, Jair, sędziowie mniejsi, sędziowie więksi, Księga Sędziów, teologia deuteronomistyczna

Keywords: Tola, Jair, minor judges, major judges, the Book of Judges, deuteronomistic theology 


\section{Sources about Tola and Jair in the Deuteronomistic Structure of the Book of Judges \\ Summary}

The primary narratives in the Book of Judges are constructed around the recurring cycle of apostasy - oppression - plea for divine deliverance through the judge $(2,10-3,6 ; 3,7-16,31)$. Three times, however, these narratives are interrupted by brief notices on six additional men who exercised leadership in Israel during the pre-monarchic period of Israel's settlement in Canaan (3,31; 10,1-5; 12,8-15). The brevity of the Shamgar, Tola, Jair, Ibzan, Elon, Abdon traditions and their unconventional literary nature within the context of the narrative cycles of oppression and deliverance have led critical scholarship generally to recognize these verses as late insertions. The minor judges are named in two summary notes framing the Jephthah narratives $(10,6-12,7)$ in 10,1-5 and 12,8-15. Except for Shamgar and Tola, who is also credited with saving Israel, these do not seem to fit the pattern of the main characters in the book. But this does not mean that these governors played a less important role than the major judges. The differences in presentation derive from the sources used by the Deuteronomistic narrator (family/tribal chronicles; folk narratives) and his literary and theological concept. 